Harry HX Xia, PhD, MD, Series Editor

\title{
DNA methylation in hepatocellular carcinoma
}

\author{
Iris Tischoff, Andrea Tannapfel
}

Iris Tischoff, Andrea Tannapfel, Institute of Pathology, RuhrUniversity of Bochum, Bürkle-de-la-Camp-Platz 1, Bochum 44789, Germany

Correspondence to: Iris Tischoff, MD, Institute of Pathology, Ruhr-University of Bochum, Bürkle-de-la-Camp-Platz 1, Bochum 44789, Germany. iris.tischoff@rub.de

Telephone: +49-234-3024955 Fax: +49-234-3024809

Received: October 30, 2007 Revised: January 5, 2008

\begin{abstract}
As for many other tumors, development of hepatocellular carcinoma (HCC) must be understood as a multistep process with accumulation of genetic and epigenetic alterations in regulatory genes, leading to activation of oncogenes and inactivation or loss of tumor suppressor genes (TSG). In the last decades, in addition to genetic alterations, epigenetic inactivation of (tumor suppressor) genes by promoter hypermethylation has been recognized as an important and alternative mechanism in tumorigenesis. In HCC, aberrant methylation of promoter sequences occurs not only in advanced tumors, it has been also observed in premalignant conditions just as chronic viral hepatitis B or C and cirrhotic liver. This review discusses the epigenetic alterations in hepatocellular carcinoma focusing DNA methylation.
\end{abstract}

(c) 2008 WJG. All rights reserved.

Key words: Hepatocellular carcinoma; DNA methylation; Histone modification; Tumor suppressor genes

Peer reviewer: Sharon Demorrow, Division of Research and Education, Scott and White Hospital and The Texas A\&M University System, Health Science Center College of Medicine, Temple, Texas 76504, United States

Tischoff I, Tannapfel A. DNA methylation in hepatocellular carcinoma. World J Gastroenterol 2008; 14(11): 1741-1748 Available from: URL: http://www.wjgnet.com/1007-9327/14/1741.asp DOI: http://dx.doi.org/10.3748/wjg.14.1741

\section{INTRODUCTION}

Hepatocellular carcinoma (HCC) is one of the most common cancer worldwide. It shows a wide geographical variation with low incidence areas in North America and Europe and high incidence areas in Africa and Asia.
$70 \%-80 \%$ of hepatocellular carcinoma occurs in cirrhotic liver. In high incidence areas, such as Asia and Africa, HCC is strongly associated with chronic viral hepatitis B and C and liver cirrhosis. Nutritional factors, toxins and metabolic diseases contribute also to hepatocarcinogenesis ${ }^{[1,2]}$.

As for many other tumors, development of HCC is due to a multistep process with accumulation of genetic and epigenetic alterations in regulatory genes, leading to activation of oncogenes and inactivation or loss of tumor suppressor genes (TSG).

In the last three decades, cancer has been understood as a summary of altered genetic and epigenetic events. The epigenetic pathway is, in contrast to genetic events, a reversible alteration and characterized by three main mechanisms: (1) DNA hypermethylation leading to inactivation, (2) DNA hypomethylation causing genomic instability, (3) histone modifications affecting chromatin conformation.

These processes, especially aberrant DNA methylation and histone modifications, are closely linked with each other by a protein complex of transcript activators and repressors and alter mRNA transcript expression of affected genes ${ }^{[3]}$.

Characteristically, DNA methylation does not change the genetic information. It just alters the readability of the DNA and results in inactivation of genes by subsequent mRNA transcript repression.

In humans and other mammals, CpG island methylation is an important physiological mechanism. The inactivated X-chromosome of females, silenced alleles of imprinted genes or inserted viral genes and repeat elements are inactivated through promoter methylation ${ }^{[4,5]}$.

\section{DNA HYPERMETHYLATION}

\section{Promoter hypermethylation}

Hypermethylation of $\mathrm{CpG}$ islands in promoter sequences is associated with silencing of tumor suppressor genes and tumor-related genes by subsequent downregulation of mRNA transcript expression. Epigenetic silenced genes are involved in important molecular pathways of carcinogenesis e.g., cell cycle regulation, apoptosis, DNA repair or cell adhesion.

According to other types of malignant tumors, in hepatocellular carcinomas, aberrant methylation of several TSG and tumor-related genes such as RASSF1A, bMLH1 or SOCS1 was frequently observed ${ }^{[6]}$.

CpG island hypermethylation is not only seen in HCC 
Table 1 Methylation in hepatocellular carcinoma

\begin{tabular}{|c|c|c|c|c|}
\hline Gene & Location & Function & $\begin{array}{l}\text { Methylation } \\
\text { frequency (\%) }\end{array}$ & Ref. \\
\hline $\mathrm{p} 16^{\mathrm{INK4a}}$ & $9 \mathrm{q} 21$ & CDK inhibitor & $17-83$ & {$[10,11]$} \\
\hline $\mathrm{p} 14^{\mathrm{ARF}}$ & $9 q 21$ & MDM2 inhibitor & $25-30$ & {$[7,12]$} \\
\hline CASP8 & $2 q 33$ & Apoptosis & 72 & [17] \\
\hline TMS1/ASC & 16p11.2 & Apoptosis & 80 & [23] \\
\hline E-Cadherin & $16 \mathrm{q} 22.1$ & Cell adhesion & $33-67$ & {$[28-30]$} \\
\hline M-Cadherin & $16 \mathrm{q} 24.1$ & Cell adhesion & 55 & [34] \\
\hline H-Cadherin & $16 \mathrm{q} 24.2-3$ & Cell adhesion & 21 & [17] \\
\hline TIMP3 & $22 q 12$ & MMP inhibitor & 13-19 & [37-39] \\
\hline hMLH1 & 3 p21.3 & Mismatch repair & $18-44$ & {$[47-50]$} \\
\hline hMSH2 & $2 p 21-22$ & Mismatch repair & 68 & {$[47,49,50]$} \\
\hline hMSH3 & $5 q 11-12$ & Mismatch repair & 75 & {$[47,49,50]$} \\
\hline MGMT & $10 \mathrm{q} 26$ & DNA repair & $22-39$ & [53-55] \\
\hline GSTP1 & $11 \mathrm{q} 13$ & Detoxification & $41-58$ & {$[53,58-61]$} \\
\hline SOCS-1 & 16p13.13 & Cytokine inhibitor & 60 & [67] \\
\hline SOCS-3 & $17 \mathrm{q} 25.3$ & Cytokine inhibitor & 33 & {$[68]$} \\
\hline RASSF1A & $3 p 21.3$ & Apoptosis & 54-95 & {$[71,75,76]$} \\
\hline BLU & $3 \mathrm{p} 21.3$ & Unknown & 20 & [71] \\
\hline SEMA3B & 3p21.3 & Apoptosis & 80 & [71] \\
\hline FHIT & 3p14.2 & histidine triad protein & 71 & [86] \\
\hline
\end{tabular}

tumor tissue. Even in premalignant conditions such as dysplastic nodules or cirrhotic liver, promoter methylation of several kinds of TSG, e.g. E-cadherin, GSTP1 or $6^{\text {Ink4a }}$ was demonstrated (Table 1 shows promoter methylation of different tumor-related genes in HCC).

\section{Proliferation and apoptosis}

One of the most important pathways affected in HCC are the $\mathrm{Rb}$ (Retinoblastoma) gene and INK4a-ARF pathway ${ }^{[7]}$. The INK4a-ARF locus is coding two cell-cycle regulatory proteins, $\not 16^{I N K A a}$ and $p 14^{A R F}$, acting through the Rb-CDK4 and $\mathrm{p} 53$ pathways. $p 16^{I N K 4 a}$ binds to cyclin-dependent protein kinase 4 (CDK4) and inhibits the ability of CDK4 to interact with cyclin D1. p14 ${ }^{A R F}$ prevents the $p 53$ degradation through its binding to MDM-2 and induces cell cycle arrest ${ }^{[8,9]}$.

$p 16^{I N K 4 a}$ is one of the most altered tumor suppressor gene in human cancer. In HCC, loss of $p 16^{\text {INK } 4 a}$ is mainly caused by aberrant promoter methylation, whereas deletions and mutations of this gene locus are infrequently seen. CPG island promoter methylation was reported from $55 \%$ to $73 \%$, but aberrant methylation occurred also in non-cancerous liver tissue with cirrhosis in $29 \%$ or chronic hepatitis $\mathrm{B}$ and $\mathrm{C}$ up to $23 \% \%^{[10,11]}$. Compared to $p 16^{\text {INK4a }}$ methylation, $p 14^{A R F}$ promoter methylation was observed less frequently in $8 \%$ to $20 \%$ of HCC. It was demonstrated that inactivation of $p 14^{A R F}$ is due to homozygous deletions. No correlation was found between $p 53$ mutations and promoter methylation of $\mathrm{p} 16^{\text {INK4a }}$ or $p 14^{4 \mathrm{RH}[7,12]}$.

Caspase 8 (CASP8) is a key apoptotic gene that is involved in death receptor and the mitochondrial pathways and acts as initiator CASP ${ }^{[13]}$. CASP8 is silenced by aberrant hypermethylation of its promoter in childhood neuroblastomas ${ }^{[14,15]}$. In HCC, CASP 8 aberrant promoter methylation was reported by $\mathrm{Yu}$ et $a^{\left[{ }^{16]}\right]}$ with a frequency up to $72 \%$.

TMS1/ASC, another proapoptotic gene, functions as a negative regulator of nuclear factor kappaB (NF-kB) and blocks transcription of survival signals ${ }^{[17]}$. First, TSM1 was identified as a target of methylation-induced silencing in cell lines overexpressing DNMT1. Epigenetic inactivation of TMS1 was demonstrated in human glioblastomas, ovarian cancer, human melanoma, colorectal carcinomas or in lung cancer and breast cancer ${ }^{[18-22]}$. In HCC, TMS1 promoter methylation was observed in $80 \%{ }^{[23]}$.

In hepatocellular carcinoma cell lines, restoration of TMS1 transcript was induced by demethylating agent 5'-AZA and trichostatin, a histone deacetylase inhibitor. Furthermore, in these cell lines TMS1 DNA methylation was associated with histone $\mathrm{H} 3$ lysine 9 hypoacetylation and trimethylation ${ }^{[24]}$.

\section{Cell adhesion and invasion}

E-cadherin (CDH1): E-cadherin, a member of calciummediated membrane glycoproteins, is expressed in all epithelial cells acting as an adhesion molecule. Inactivation of E-cadherin induces loss of adherens junctions and impairment of cell adhesiveness and cell proliferation signalling pathways. In tumours, reduction of E-cadherin expression results in tumour progression, cell invasion and formation of metastasis ${ }^{[25,26]}$.

Downregulation of E-cadherin, caused by genetic and epigenetic mechanism, is a frequent event in most type of epithelial carcinomas. In poorly-differentiated breast and gastric cancer, somatic mutations of E-cadherin are frequently found. Further, in all cases of familial gastric cancer, loss of E-cadherin is mainly caused by germline mutations ${ }^{[27]}$. In other types of tumors, mutations are infrequent events and repression of E-cadherin is mainly caused by aberrant promoter methylation.

In according to CC, mutations of E-cadherin are rare events in HCC. Reduced or loss of E-cadherin expression is mainly caused by aberrant $\mathrm{CpG}$ island methylation with a detectable frequency from $33 \%$ to $67 \%{ }^{[28-30}$. Wei et a ${ }^{[31]}$ described, that loss of E-cadherin was closely associated with loss of heterozygosity (LOH) of E-cadherin and $\mathrm{CPG}$ hypermethylation. In precancerous conditions just as dysplastic nodules or liver tissue with chronic hepatitis or cirrhosis, aberrant E-cadherin methylation was detected in $8 \%$ and $46 \%$, respectively ${ }^{[29,30]}$.

Other factors, except epigenetic inactivation or mutations, leading to inactivation of E-cadherin include transcriptional repression by binding of transcriptional factors, e.g. the repressors Snail or Sip-1 to CDH1-E box elements ${ }^{[32,33]}$.

But not only E-cadherin, as a member of cadherin genes, is epigenetically altered in HCC. Yamada $e t a^{[34]}$ reported the highest methylation frequency of $\mathrm{M}$-cadherin with a frequency to $55 \%$ among seven elucidated cadherin genes. Methylation-induced silencing of $\mathrm{H}$-Cadherin (CDH13) was observed by Yu et a $l^{[17]}$, reaching $21 \%$.

TIMP-3: Tissue inhibitor of metalloproteinase-3 (TIMP-3) leads to inhibition of cell migration and angiogenesis. In human carcinoma cell lines, overexpression of TIMP-3 suppresses cell growth and induces apoptosis by stabilization of TNF-alpha receptors on the cell surface $^{[35,36]}$. A TIMP-3 downregulation was demonstrated 
in different kinds of tumors, mostly mediated by $\mathrm{CpG}$ island promoter methylation ${ }^{[6]}$.

In HCC, TIMP-3 methylation is an infrequent event reaching $13 \%$ to $19 \%$. No methylation was found in normal liver tissue. Lü $e t$ a ${ }^{[37]}$ demonstrated TIMP-3 methylation in $25 \%$ of hepatocellular cancer emboli in portal veins. The aberrant promoter methylation is accompanied by loss or reduced TIMP-3 mRNA and protein expression ${ }^{[37-39]}$.

TFPI-2: TFPI-2 is a Kunitz-type serine protease inhibitor that represses cellular invasion in several kinds of tumors, e.g. in lung cancer or pancreas carcinomas, by suppressing plasmin-mediated activation of MMP-1 and MMP-3 or inhibition of plasmin and trypsin activity ${ }^{[40-43]}$.

Wong et a ${ }^{[44]}$ observed TFPI-2 downregulation with reduced or loss mRNA transcript expression in HCC with a frequency of $90 \%$. In $47 \%$ of the observed HCC, aberrant $\mathrm{CpG}$ methylation was seen, but not in normal liver tissue. In HCC cell lines with epigenetically induced silencing, a TFPI-2 mRNA transcript re-expression was induced by combined treatment with the demethylating agent 5'-AZA-DC and the histone deacetylase inhibitor TSA.

\section{DNA repair}

Mismatch repair system: Defects in DNA repair mechanisms may result in accumulation of mutations and genomic instability. The mismatch repair system (MMR) is one of the most important DNA repair mechanisms correcting errors in DNA replication. Defects of the MMR leading to microsatellite instabilities (MSI) have been observed in approximately $15 \%$ of sporadic colorectal and gastric carcinomas ${ }^{[45,46]}$. Promoter methylation of MMR genes in HCC occurred with a frequency of $5 \%$ to $13 \%$ for $h M L H 1,68 \%$ for $h M S H 2$ and $75 \%$ for $h M S H 3$. A high methylation frequency of $h M S H 2$ and $h M S H 3$ was observed in HCC corresponding non neoplastic liver tissue, especially in cirrhotic liver tissue, reaching $55 \%$ and $70 \%$, but not in normal liver tissue. No correlation was found neither to viral hepatitis nor to MSI status and DNA methylation of analyzed MMR genes ${ }^{[47-50]}$.

MGMT (O6-methylguanine DNA methyltransferase): O6-methylguanine DNA methyltransferase (MGMT) is another important DNA repair gene with the highest activity in the liver ${ }^{[5]}$. MGMT protects cells from DNA damage caused by mutagenic and cytotoxic agents leading to alkylation at O6-guanine. Loss or reduced MGMT expression due to $\mathrm{CpG}$ islands methylation was detected in several kinds of human cancers ${ }^{[52]}$. In HCC, aberrant methylation occurred with a frequency of $22 \%$ to $39 \%$, whereas the MGMT promoter shows higher methylation levels in chronic viral hepatitis associated HCC ${ }^{[53-55]}$. Interestingly, Su et al ${ }^{[53]}$ reported that $M G M T$ promoter methylation occurred to a similar extent in non neoplastic liver tissue compared to HCC.

GSTP1 (Glutathione S-transferase P1): The detoxificating glutathione S-transferase P1 (GSTP1) gene protects cells from cytotoxic and carcinogenic influences in due to inactivation of electrophilic carcinogens by conjugation with glutathione. Promoter methylation of GSTP1 is best analyzed in prostate cancer. GSTP1 methylation is an early event in prostatic carcinogenesis, because in high-grade prostatic intraepithelial neoplasia loss of GSTP1 expression is caused by DNA methylation. Many other tumor types including breast cancer and cholangiocarcinoma showed a GSTP1 hypermethylated promoter ${ }^{[5,57]}$. In HCC, methylation of the GSTP1 gene occurred in $41 \%$ to $85 \%{ }^{[53,58-61]}$. Zhang elucidated GSTP1 methylation in HCC in presence of environmental chemical carcinogens. A significant correlation was observed with higher aflatoxin $\mathrm{B}_{1}\left(\mathrm{AFB}_{1}\right)$-DNA adducts in tumor tissue in contrast to tumor tissue without or lower levels of $\mathrm{AFB}_{1}$-DNA adducts. However, no association was found between GSTP1 methylation and polycyclic aromatic hydrocarbon-DNA adducts ${ }^{[59]}$. So far, aberrant methylation of GSTP1 is not only detectable in tumor tissue, Wang et al ${ }^{[62]}$ observed a GSTP1 hypermethylation in serum of HCC patients.

Suppressors of cytokine signaling (SOCS): Suppressors of cytokine signaling 1 and 3 (SOCS-1 and SOCS-3) are intracellular proteins that act as negative regulators of Janus kinase (JAK) and signal transducer and activators of signaling pathways (STAT). The JAK/STAT signaling pathway plays an important role in cell growth and differentiation or immune reaction mediated by cytokines. Cytokines activate JAK's by binding to membrane receptors that leads to phosphorylation of STAT's and activates target genes. SOCS1 and SOCS-3 bind direct and indirect to JAK's and inhibit the phosphorylation of STAT's and activation of target genes ${ }^{[3,6,64]}$.

Aberrant methylation of SOCS-1 and SOCS-3 promoter sequence has been reported in several kinds of human cancer. SOCS -1 and SOCS-3 CpG island hypermethylation is an early event in human carcinogenesis. Recently, we have shown methylation-induced downregulation of SOCS-1 and SOCS-3 in precursor lesions of Barrett's adenocarcinomas and precursor lesions of squamous carcinomas of head and neck ${ }^{[65,66]}$. In HCC, aberrant promoter methylation of SOCS-1 and SOCS-3 occurred with a frequency of $60 \%$ and $33 \%$, respectively ${ }^{[67,68]}$. Methylation of the SOCS-1 gene was detected in HCVinduced chronic hepatitis and liver cirrhosis, reaching $45 \%$, whereas the methylation frequency increased with fibrosis stage with the highest proportion in liver cirrhosis ${ }^{[69,70]}$.

\section{Methylation hot spot $3 p$}

The short arm of human chromosome 3 belongs to regional methylation hot spots in addition to chromosomal locus $11 \mathrm{p}$ and $17 \mathrm{p}$. Alterations of the genetic information on chromosome 3 are one of the most frequent and earliest steps in the carcinogenesis of several types of tumors. LOH of chromosome 3p occurred in about 30\% of hepatocellular carcinomas ${ }^{[71]}$.

In different kinds of human cancer, epigenetic inactivation via promoter methylation of several genes located on 3p, including RASSF1A on 3p21.3, bMLH1 at $3 \mathrm{p} 21.3, \mathrm{RAR} \beta 2$ at $3 \mathrm{p} 24.2$, was shown.

One of the most frequent observed and most 
epigenetically inactivated genes of $3 \mathrm{p}$ is $\mathrm{RASSF} 1 \mathrm{~A}$, a multifunctional tumor suppressor gene that protects cells from genomic instability and transformation by stabilizing the microtubules ${ }^{[72,73]}$. An aberrant promoter methylation was detected in about $50 \%$ of malignant tumors. In renal cell carcinoma and small cell lung cancer, the highest prevalence was observed, reaching about $91 \%{ }^{[74]}$. In HCC, hypermethylation occurred in approximately $54 \%$ to 95\%, whereas HBV-associated HCC showed higher levels of RASSF1A methylation compared to HCC without risk factors. RASSF1 $A$ methylation occurs not only in HCC, methylation is even observed in non-neoplastic precancerous conditions like cirrhotic liver and chronic hepatitis $^{[71]}$.

Semaphorin 3B (SEMA3B) and BLU are two other putative tumour suppressor genes located on $3 \mathrm{p} 21.3$, whereas the function of $B L U$ still remains unclear. In lung cancer, $B L U$ overexpression inhibits tumor colony formation efficiency. Qiu et $a l^{77]}$ reported that BLU might function as an environmental stress-responsive gene, regulated by E2F, at least in nasopharyngeal carcinomas. However, BLU methylation is a rare event in human cancer. We detected $B L U$ promoter methylation in about $20 \%$ of our examined HCC ${ }^{[71,78]}$.

$S E M A 3 B$, a member of the Semaphorin family, suppresses tumor formation in lung cancer and induces apoptosis. It has been demonstrated that $S E M A 3 B$ induced apoptosis is antagonized by $V E G F^{165}$ in due to an interaction with NP-1 receptor ${ }^{[79,80]}$.

Aberrant methylation of $S E M A 3 B$ was detected in lung cancer and gliomas ${ }^{[81,82]}$. We reported a high prevalence of $S E M A 3 B$ methylation in HCC, reaching $80 \%$. In contrast, the tumor surrounding non-neoplastic liver exhibited an unmethylated $S E M A 3 B$ promoter. Further, RASSF1 $A$ and $S E M A 3 B$ expression was restored by treatment with the demethylating drug 5-AZA-C in HCC cell lines, suggesting that promoter hypermethylation is responsible for silencing transcript expression ${ }^{[71,72,81]}$.

The fragile histidine triad (FHIT) gene, located to 3p14.2, embraces FRA3b, the most actively fragile site in humans ${ }^{[3,84]}$. Functional and structural alterations of FHIT were identified in several kinds of human cancer. Methylation induced silencing was described in lung and breast cancers ${ }^{[85]}$. In HCC, promoter methylation of FHIT is a frequent and early event. Sun et al ${ }^{[86]}$ observed FHIT hypermethylation with a frequency of $71 \%$ in HCC, $64 \%$ in non neoplastic liver tissue and $14 \%$ in normal liver.

\section{CpG island methylator phenotype (CIMP)}

Carcinomas with high rates of accumulated aberrant promoter methylation of tumor-related genes are characterized as $\mathrm{CIMP}^{+}$(CpG island methylator phenotype). $\mathrm{CIMP}^{+}$was first described for colorectal and gastric cancer by Toyota and Issa in $1999^{[87,88]}$. Shen et a ${ }^{[89]}$ reported that $\mathrm{CIMP}^{+}$is associated with environmental exposures in HCC. HCC from patients without precancerous conditions or risk factors, respectively, showed significantly lower levels of methylation than HCC arising from patients with chronic hepatitis $\mathrm{B}$ and $\mathrm{C}$ or patients with cirrhosis.

CIMP positive HCC (tumours with five genes that are concordantly methylated) showed a significantly association with methylation of the TSG $p 14, p 15, p 16 \mathrm{ER}$, RASSF1 $A$ or $W T 1$ and elevated serum alpha-fetoprotein (AFP) levels. Further, $\mathrm{CIMP}^{+}$was commonly seen in HCC with increased serum AFP levels ${ }^{[00,91]}$.

\section{DNA-methyltransferases (DNMT)}

DNA hypermethylation is catalyzed by the family of DNA methyltransferases (DNMT) including DNMT1, DNMT3a and DNMT3b. DNMT1 is required for maintenance of DNA methylation whereas DNMT3a and DNMT3b function as de novo DNA methyltransferases ${ }^{[22-94]}$. DNMT2 was former described as DNMT because of its strong similarity with $\mathrm{m} 5 \mathrm{C}$ methyltransferases of pro- and eukaryotes. But it was recently shown that DNMT2 does not methylate DNA. It's the first described RNA cytosine methyltransferase that methylate position 38 in Aspartic acid transfer $\mathrm{RNA}^{[95]}$.

In human cancer just as in HCC, an upregulation of DNMT activity is seen in contrast to global hypomethylation. Park et a ${ }^{[96]}$ described a significantly overexpression of DNMT1 and DNMT3b in HCC compared to non-neoplastic liver tissue. DNMT3a showed similar or higher expression levels. Saito et a ${ }^{[97]}$ observed higher expression levels of all three DNMTs in HCC and cirrhotic liver than in normal liver. Increased DNMT1 and DNMT3a expression was also reported in dysplastic nodules $^{[98]}$

According to other tumors, no correlation was seen between DNMT upregulation and promoter hypermethylation-induced inactivation of tumor-related genes. The certain mechanisms of DNMT upregulation remains still unclear, but it is suggested that aberrant DNMT activity, especially of DNMT1, is due to rapid proliferation of cancer cells because DNMT1 binds to proliferating cell nuclear antigen (PCNA) ${ }^{[99-101]}$.

DNA hypomethylation on pericentromeric satellite regions results in chromosomal instability. During hepatocarcinogenesis, DNA hypomethylation of these regions was reported in HCC and precancerous conditions. The splice variant of DNMT3b, DNMT3b4 that may lack DNA methyltransferase activity is associated with DNA hypomethylation on pericentromeric satellite regions. Saito $e t a l^{102]}$ reported that overexpresssion of DNMT3b4 was seen in cirrhotic liver, chronic hepatitis and HCC whereas increased DNMT3b4 levels correlated with DNA hypomethylation on pericentromeric satellite regions.

\section{DNA HYPOMETHYLATION}

In human cancer, global DNA hypomethylation leads to genomic instability, affects repeated DNA sequences, tissue-specific genes and proto-oncogenes or causes loss of imprinting with a biallelic expression, just as in case of IGF2. Further, the level of DNA hypomethylation increases with tumor progression ${ }^{[103,104]}$. In recent years, DNA hypomethylation was shown in several human cancer and some premalignant alterations, i.e. colorectal adenomas and carcinomas, adenocarcinoma of prostate, breast cancer or intestinal type of gastric carcinoma and hepatocellular carcinoma, respectively ${ }^{[105-108]}$. 
Lin $e$ a ${ }^{1009}$ observed 5-methylcytosine (m5C) content in hepatocellular carcinogenesis by comparing hepatocellular carcinoma with non neoplastic liver, including cirrhotic livers. In all cancer tissues, 5-methylcytosine was significantly reduced. No difference of the $\mathrm{m} 5 \mathrm{C}$ content was detected in cirrhotic and non cirrhotic liver tissue. The reduced $5 \mathrm{mC}$ level was associated with large tumor size and poorly histopathological grade.

It is suggested that (re-)activation of retroposons might be associated with global hypomethylation because approximately $90 \%$ of all $\mathrm{m} 5 \mathrm{C}$ lies in these elements. An association between hypomethylation and transposon activation, especially of LINE-1 transposons, has been observed in human testicular carcinoma cell lines, urothelial carcinoma cell lines and teratocarcinoma cell lines ${ }^{[10-112]}$. But in HCC, an activation of transposable elements just as LINE-1 retrotransposons via hypomethylation could not be detected yet ${ }^{[109]}$.

\section{HISTONE MODIFICATION}

Histone modifications are strongly associated with formation of the nucleosome structure and are closely linked to $\mathrm{CPG}$ island methylation by interacting with Methyl-CpG-binding proteins (MBD's) and DNA methyltransferases (DNMT's). Modifications including methylation, acetylation or phosphorylation of certain position of the histone tails. Whereas histone methylation is associated either to activation or to repression, histone hypoacetylation mediated by histone deacetylases leads mostly to DNA relaxation and subsequent accessibility for transcriptional factors with repression of transcription.

Lee et a ${ }^{[113]}$ reported that HCC with low survival expressed higher levels of genes involved in histone modifications just as PTMA and SET, two proteins that are members of inhibitors of histoneacetyltransferases complex.

P73, a member of the TP53 family represses AFP expression during normal hepatic development by chromatin structure alterations. In hepatoma cells, transactivated p73 suppresses endogenous AFP transcription via reducing of acetylated histone $\mathrm{H} 3$ lysine 9 and increasing dimethylated histone $\mathrm{H} 3$ lysine $9^{[114]}$.

\section{CONCLUSION}

In hepatocarcinogenesis, aberrant methylation of tumor related genes occurs not only in advanced tumour stages, it's a frequent and early event. Promoter methylation of different kinds of tumor suppressor genes including $p 16$, SOCS1 and SOCS 3 or RASSF1A, has been demonstrated in premalignant conditions just as chronic hepatitis or liver cirrhosis. Moreover, the frequency of aberrant promoter methylation increases during the progression from precancerous lesion to HCC. In HBV or HCV-associated chronic hepatitis, methylation frequency of detected genes is significantly higher than in non-neoplastic non-viral liver tissue. Therefore, epigenetic changes in preneoplastic or early neoplastic stages may serve as indicator or "biomarker" for screening of patients with an increased risk for HCC.
Further, HCC is one of the most common causes of cancer death worldwide with a poor prognosis. Only few therapeutic interventions exist. It was demonstrated that re-expression of tumor suppressor genes that are epigenetically silenced is possible by using demethylating and histone modifying agents. In the next years, this might be a possible therapeutic approach analogue to other malignant diseases, e.g. myelodysplastic syndrome, but the used therapeutic agents that influence DNA hypermethylation are toxic and lead to genome wide alteration of the methylation pattern with possible activating of oncogenes or imprinted genes. Another possible aspect of chemotherapy might be to modulate the epigenetically involved pathways by using small molecules that are more specific. But further investigations in clinical trails are needed to prove and integrate epigenetic pathway modulating agents.

\section{REFERENCES}

1 Beasley RP, Hwang LY, Lin CC, Chien CS. Hepatocellular carcinoma and hepatitis B virus. A prospective study of 22707 men in Taiwan. Lancet 1981; 2: 1129-1133

2 Parkin DM, Bray F, Ferlay J, Pisani P. Estimating the world cancer burden: Globocan 2000. Int J Cancer 2001; 94: 153-156

3 Baylin SB, Herman JG. DNA hypermethylation in tumorigenesis: epigenetics joins genetics. Trends Genet 2000; 16: $168-174$

4 Riggs AD, Pfeifer GP. X-chromosome inactivation and cell memory. Trends Genet 1992; 8: 169-174

5 Razin A, Cedar H. DNA methylation and genomic imprinting. Cell 1994; 77: 473-476

6 Esteller M, Corn PG, Baylin SB, Herman JG. A gene hypermethylation profile of human cancer. Cancer Res 2001; 61: $3225-3229$

7 Tannapfel A, Busse C, Weinans L, Benicke M, Katalinic A Geissler F, Hauss J, Wittekind C. INK4a-ARF alterations and p53 mutations in hepatocellular carcinomas. Oncogene 2001; 20: 7104-7109

8 Liggett WH Jr, Sidransky D. Role of the p16 tumor suppressor gene in cancer. J Clin Oncol 1998; 16: 1197-1206

9 Sharpless NE, DePinho RA. The INK4A/ARF locus and its two gene products. Curr Opin Genet Dev 1999; 9: 22-30

10 Tannapfel A, Wittekind C. Genes involved in hepatocellular carcinoma: deregulation in cell cycling and apoptosis. Virchows Arch 2002; 440: 345-352

11 Kaneto H, Sasaki S, Yamamoto H, Itoh F, Toyota M, Suzuki H, Ozeki I, Iwata N, Ohmura T, Satoh T, Karino Y, Satoh T, Toyota J, Satoh M, Endo T, Omata M, Imai K. Detection of hypermethylation of the p16(INK4A) gene promoter in chronic hepatitis and cirrhosis associated with hepatitis B or C virus. Gut 2001; 48: 372-377

12 Peng CY, Chen TC, Hung SP, Chen MF, Yeh CT, Tsai SL, Chu CM, Liaw YF. Genetic alterations of INK4alpha/ARF locus and p53 in human hepatocellular carcinoma. Anticancer Res 2002; 22: 1265-1271

13 Medema JP, Scaffidi C, Kischkel FC, Shevchenko A, Mann $\mathrm{M}$, Krammer PH, Peter ME. FLICE is activated by association with the CD95 death-inducing signaling complex (DISC). EMBO J 1997; 16: 2794-2804

14 Teitz T, Wei T, Valentine MB, Vanin EF, Grenet J, Valentine VA, Behm FG, Look AT, Lahti JM, Kidd VJ. Caspase 8 is deleted or silenced preferentially in childhood neuroblastomas with amplification of MYCN. Nat Med 2000; 6: 529-535

15 Banelli B, Casciano I, Croce M, Di Vinci A, Gelvi I, Pagnan G, Brignole C, Allemanni G, Ferrini S, Ponzoni M, Romani M. Expression and methylation of CASP8 in neuroblastoma: identification of a promoter region. Nat Med 2002; 8: 1333-1335; author reply 1335 
16 Yu J, Ni M, Xu J, Zhang H, Gao B, Gu J, Chen J, Zhang L, Wu M, Zhen S, Zhu J. Methylation profiling of twenty promoterCpG islands of genes which may contribute to hepatocellular carcinogenesis. BMC Cancer 2002; 2: 29

17 McConnell BB, Vertino PM. TMS1/ASC: the cancer connection. Apoptosis 2004; 9: 5-18

18 Stone AR, Bobo W, Brat DJ, Devi NS, Van Meir EG, Vertino PM. Aberrant methylation and down-regulation of TMS1/ ASC in human glioblastoma. Am J Pathol 2004; 165: 1151-1161

19 Terasawa K, Sagae S, Toyota M, Tsukada K, Ogi K, Satoh A, Mita H, Imai K, Tokino T, Kudo R. Epigenetic inactivation of TMS1/ASC in ovarian cancer. Clin Cancer Res 2004; 10: 2000-2006

20 Guan X, Sagara J, Yokoyama T, Koganehira Y, Oguchi M, Saida T, Taniguchi S. ASC/TMS1, a caspase-1 activating adaptor, is downregulated by aberrant methylation in human melanoma. Int J Cancer 2003; 107: 202-208

21 Yokoyama T, Sagara J, Guan X, Masumoto J, Takeoka M, Komiyama Y, Miyata K, Higuchi K, Taniguchi S. Methylation of ASC/TMS1, a proapoptotic gene responsible for activating procaspase-1, in human colorectal cancer. Cancer Lett 2003; 202: 101-108

22 Virmani A, Rathi A, Sugio K, Sathyanarayana UG, Toyooka S, Kischel FC, Tonk V, Padar A, Takahashi T, Roth JA, Euhus DM, Minna JD, Gazdar AF. Aberrant methylation of TMS1 in small cell, non small cell lung cancer and breast cancer. Int J Cancer 2003; 106: 198-204

23 Kubo T, Yamamoto J, Shikauchi Y, Niwa Y, Matsubara K, Yoshikawa H. Apoptotic speck protein-like, a highly homologous protein to apoptotic speck protein in the pyrin domain, is silenced by DNA methylation and induces apoptosis in human hepatocellular carcinoma. Cancer Res 2004; 64: 5172-5177

24 Zhang C, Li H, Zhou G, Zhang Q, Zhang T, Li J, Zhang J, Hou J, Liew CT, Yin D. Transcriptional silencing of the TMS1/ASC tumour suppressor gene by an epigenetic mechanism in hepatocellular carcinoma cells. J Pathol 2007; 212: 134-142

25 Hashimoto M, Niwa O, Nitta Y, Takeichi M, Yokoro K. Unstable expression of E-cadherin adhesion molecules in metastatic ovarian tumor cells. Jpn J Cancer Res 1989; 80: 459-463

26 Bussemakers MJ, van Moorselaar RJ, Giroldi LA, Ichikawa T, Isaacs JT, Takeichi M, Debruyne FM, Schalken JA. Decreased expression of E-cadherin in the progression of rat prostatic cancer. Cancer Res 1992; 52: 2916-2922

27 Guilford P, Hopkins J, Harraway J, McLeod M, McLeod N, Harawira P, Taite H, Scoular R, Miller A, Reeve AE. E-cadherin germline mutations in familial gastric cancer. Nature 1998; 392: 402-405

28 Matsumura T, Makino R, Mitamura K. Frequent downregulation of $\mathrm{E}$-cadherin by genetic and epigenetic changes in the malignant progression of hepatocellular carcinomas. Clin Cancer Res 2001; 7: 594-599

29 Kwon GY, Yoo BC, Koh KC, Cho JW, Park WS, Park CK. Promoter methylation of E-cadherin in hepatocellular carcinomas and dysplastic nodules. J Korean Med Sci 2005; 20: 242-247

30 Kanai Y, Ushijima S, Hui AM, Ochiai A, Tsuda H, Sakamoto $\mathrm{M}$, Hirohashi S. The E-cadherin gene is silenced by $\mathrm{CpG}$ methylation in human hepatocellular carcinomas. Int J Cancer 1997; 71: 355-359

31 Wei Y, Van Nhieu JT, Prigent S, Srivatanakul P, Tiollais $\mathrm{P}$, Buendia MA. Altered expression of E-cadherin in hepatocellular carcinoma: correlations with genetic alterations, beta-catenin expression, and clinical features. Hepatology 2002; 36: 692-701

32 Batlle E, Sancho E, Franci C, Dominguez D, Monfar M, Baulida J, Garcia De Herreros A. The transcription factor snail is a repressor of E-cadherin gene expression in epithelial tumour cells. Nat Cell Biol 2000; 2: 84-89

33 Cano A, Perez-Moreno MA, Rodrigo I, Locascio A, Blanco MJ, del Barrio MG, Portillo F, Nieto MA. The transcription factor snail controls epithelial-mesenchymal transitions by repressing E-cadherin expression. Nat Cell Biol 2000; 2: 76-83

34 Yamada S, Nomoto S, Fujii T, Takeda S, Kanazumi N, Sugimoto H, Nakao A. Frequent promoter methylation of M-cadherin in hepatocellular carcinoma is associated with poor prognosis. Anticancer Res 2007; 27: 2269-2274

35 Bian J, Wang Y, Smith MR, Kim H, Jacobs C, Jackman J, Kung HF, Colburn NH, Sun Y. Suppression of in vivo tumor growth and induction of suspension cell death by tissue inhibitor of metalloproteinases (TIMP)-3. Carcinogenesis 1996; 17: 1805-1811

36 Mannello F, Gazzanelli G. Tissue inhibitors of metalloproteinases and programmed cell death: conundrums, controversies and potential implications. Apoptosis 2001; 6: 479-482

37 Lu GL, Wen JM, Xu JM, Zhang M, Xu RB, Tian BL. Relationship between TIMP-3 expression and promoter methylation of TIMP-3 gene in hepatocellular carcinoma. Zhonghua Binglixue Zazhi 2003; 32: 230-233

38 Lee S, Lee HJ, Kim JH, Lee HS, Jang JJ, Kang GH. Aberrant CpG island hypermethylation along multistep hepatocarcinogenesis. Am J Pathol 2003; 163: 1371-1378

39 Lai HJ, Lo SJ. Epigenetic methylation of TIMP-3 may play a role in HBV-associated hepatocellular carcinoma. Chang Gung Med J 2005; 28: 453-455

40 Rao CN, Liu YY, Peavey CL, Woodley DT. Novel extracellular matrix-associated serine proteinase inhibitors from human skin fibroblasts. Arch Biochem Biophys 1995; 317: 311-314

41 Sprecher CA, Kisiel W, Mathewes S, Foster DC. Molecular cloning, expression, and partial characterization of a second human tissue-factor-pathway inhibitor. Proc Natl Acad Sci USA 1994; 91: 3353-3357

42 Rao CN, Cook B, Liu Y, Chilukuri K, Stack MS, Foster DC, Kisiel W, Woodley DT. HT-1080 fibrosarcoma cell matrix degradation and invasion are inhibited by the matrixassociated serine protease inhibitor TFPI-2/33 kDa MSPI. Int Cancer 1998; 76: 749-756

43 Rao CN, Mohanam S, Puppala A, Rao JS. Regulation of ProMMP-1 and ProMMP-3 activation by tissue factor pathway inhibitor-2/matrix-associated serine protease inhibitor. Biochem Biophys Res Commun 1999; 255: 94-98

44 Wong CM, Ng YL, Lee JM, Wong CC, Cheung OF, Chan CY, Tung EK, Ching YP, Ng IO. Tissue factor pathway inhibitor-2 as a frequently silenced tumor suppressor gene in hepatocellular carcinoma. Hepatology 2007; 45: 1129-1138

45 Kim H, Jen J, Vogelstein B, Hamilton SR. Clinical and pathological characteristics of sporadic colorectal carcinomas with DNA replication errors in microsatellite sequences. Am J Pathol 1994; 145: 148-156

46 Oliveira C, Seruca R, Seixas M, Sobrinho-Simoes M. The clinicopathological features of gastric carcinomas with microsatellite instability may be mediated by mutations of different "target genes": a study of the TGFbeta RII, IGFII R, and BAX genes. Am J Pathol 1998; 153: 1211-1219

47 Park JH, Cho SB, Lee WS, Park CH, Joo YE, Kim HS, Choi SK, Rew JS, Lee JH, Kim SJ. Methylation pattern of DNA repair genes and microsatellite instability in hepatocelluar carcinoma. Korean J Gastroenterol 2006; 48: 327-336

48 Matsukura S, Soejima H, Nakagawachi T, Yakushiji H, Ogawa A, Fukuhara M, Miyazaki K, Nakabeppu Y, Sekiguchi M, Mukai T. CpG methylation of MGMT and hMLH1 promoter in hepatocellular carcinoma associated with hepatitis viral infection. Br J Cancer 2003; 88: 521-529

49 Wang L, Bani-Hani A, Montoya DP, Roche PC, Thibodeau SN, Burgart LJ, Roberts LR. hMLH1 and hMSH2 expression in human hepatocellular carcinoma. Int J Oncol 2001; 19: 567-570

50 Zhang CJ, Li HM, Yau LM, Suen KW, Zhou GY, Yu F, Liew $\mathrm{CT}$. Methylation of mismatch repair gene (MMR) in primary hepatocellular carcinoma. Zhonghua Binglixue Zazhi 2004; 33: 433-436

51 Gerson SL, Trey JE, Miller K, Berger NA. Comparison of O6alkylguanine-DNA alkyltransferase activity based on cellular DNA content in human, rat and mouse tissues. Carcinogenesis 1986; 7: 745-749

52 Esteller M, Hamilton SR, Burger PC, Baylin SB, Herman 
JG. Inactivation of the DNA repair gene O6-methylguanineDNA methyltransferase by promoter hypermethylation is a common event in primary human neoplasia. Cancer Res 1999; 59: 793-797

53 Su PF, Lee TC, Lin PJ, Lee PH, Jeng YM, Chen CH, Liang JD, Chiou LL, Huang GT, Lee HS. Differential DNA methylation associated with hepatitis B virus infection in hepatocellular carcinoma. Int J Cancer 2007; 121: 1257-1264

54 Matsukura S, Soejima H, Nakagawachi T, Yakushiji H, Ogawa A, Fukuhara M, Miyazaki K, Nakabeppu Y, Sekiguchi M, Mukai T. CpG methylation of MGMT and hMLH1 promoter in hepatocellular carcinoma associated with hepatitis viral infection. Br J Cancer 2003; 88: 521-529

55 Zhang YJ, Chen Y, Ahsan H, Lunn RM, Lee PH, Chen CJ, Santella RM. Inactivation of the DNA repair gene O6methylguanine-DNA methyltransferase by promoter hypermethylation and its relationship to aflatoxin B1-DNA adducts and p53 mutation in hepatocellular carcinoma. Int J Cancer 2003; 103: 440-444

56 Brooks JD, Weinstein M, Lin X, Sun Y, Pin SS, Bova GS, Epstein JI, Isaacs WB, Nelson WG. CG island methylation changes near the GSTP1 gene in prostatic intraepithelial neoplasia. Cancer Epidemiol Biomarkers Prev 1998; 7: 531-536

57 Esteller M, Corn PG, Urena JM, Gabrielson E, Baylin SB, Herman JG. Inactivation of glutathione S-transferase P1 gene by promoter hypermethylation in human neoplasia. Cancer Res 1998; 58: 4515-4518

58 Lee S, Lee HJ, Kim JH, Lee HS, Jang JJ, Kang GH. Aberrant $\mathrm{CpG}$ island hypermethylation along multistep hepatocarcinogenesis. Am J Pathol 2003; 163: 1371-1378

59 Zhang YJ, Chen Y, Ahsan H, Lunn RM, Chen SY, Lee PH, Chen CJ, Santella RM. Silencing of glutathione S-transferase P1 by promoter hypermethylation and its relationship to environmental chemical carcinogens in hepatocellular carcinoma. Cancer Lett 2005; 221: 135-143

60 Zhong S, Tang MW, Yeo W, Liu C, Lo YM, Johnson PJ. Silencing of GSTP1 gene by CpG island DNA hypermethylation in HBV-associated hepatocellular carcinomas. Clin Cancer Res 2002; 8: 1087-1092

61 Anzola M, Cuevas N, Lopez-Martinez M, Saiz A, Burgos JJ, de Pancorbo MM. No association between GSTP1 gene aberrant promoter methylation and prognosis in surgically resected hepatocellular carcinoma patients from the Basque Country (Northern Spain). Liver Int 2003; 23: 249-254

62 Wang J, Qin Y, Li B, Sun Z, Yang B. Detection of aberrant promoter methylation of GSTP1 in the tumor and serum of Chinese human primary hepatocellular carcinoma patients. Clin Biochem 2006; 39: 344-348

63 Starr R, Willson TA, Viney EM, Murray LJ, Rayner JR, Jenkins BJ, Gonda TJ, Alexander WS, Metcalf D, Nicola NA, Hilton DJ. A family of cytokine-inducible inhibitors of signalling. Nature 1997; 387: 917-921

64 Endo TA, Masuhara M, Yokouchi M, Suzuki R, Sakamoto H, Mitsui K, Matsumoto A, Tanimura S, Ohtsubo M, Misawa H, Miyazaki T, Leonor N, Taniguchi T, Fujita T, Kanakura Y, Komiya S, Yoshimura A. A new protein containing an SH2 domain that inhibits JAK kinases. Nature 1997; 387: 921-924

65 Weber A, Hengge UR, Bardenheuer W, Tischoff I, Sommerer F, Markwarth A, Dietz A, Wittekind C, Tannapfel A. SOCS-3 is frequently methylated in head and neck squamous cell carcinoma and its precursor lesions and causes growth inhibition. Oncogene 2005; 24: 6699-6708

66 Tischoff I, Hengge UR, Vieth M, Ell C, Stolte M, Weber A, Schmidt WE, Tannapfel A. Methylation of SOCS-3 and SOCS-1 in the carcinogenesis of Barrett's adenocarcinoma. Gut 2007; 56: 1047-1053

67 Okochi O, Hibi K, Sakai M, Inoue S, Takeda S, Kaneko T, Nakao A. Methylation-mediated silencing of SOCS-1 gene in hepatocellular carcinoma derived from cirrhosis. Clin Cancer Res 2003; 9: 5295-5298

68 Niwa Y, Kanda H, Shikauchi Y, Saiura A, Matsubara K, Kitagawa T, Yamamoto J, Kubo T, Yoshikawa H. Methylation silencing of SOCS-3 promotes cell growth and migration by enhancing JAK/STAT and FAK signalings in human hepatocellular carcinoma. Oncogene 2005; 24: 6406-6417

69 Miyoshi H, Fujie H, Moriya K, Shintani Y, Tsutsumi T, Makuuchi M, Kimura S, Koike K. Methylation status of suppressor of cytokine signaling-1 gene in hepatocellular carcinoma. J Gastroenterol 2004; 39: 563-569

70 Yoshida T, Ogata H, Kamio M, Joo A, Shiraishi H, Tokunaga Y, Sata M, Nagai H, Yoshimura A. SOCS1 is a suppressor of liver fibrosis and hepatitis-induced carcinogenesis. J Exp Med 2004; 199: $1701-1707$

71 Tischoff I, Markwarth A, Witzigmann H, Uhlmann D, Hauss J, Mirmohammadsadegh A, Wittekind C, Hengge UR, Tannapfel A. Allele loss and epigenetic inactivation of $3 p 21.3$ in malignant liver tumors. Int J Cancer 2005; 115: 684-689

72 Dammann R, Li C, Yoon JH, Chin PL, Bates S, Pfeifer GP. Epigenetic inactivation of a RAS association domain family protein from the lung tumour suppressor locus 3p21.3. Nat Genet 2000; 25: 315-319

73 Liu L, Tommasi S, Lee DH, Dammann R, Pfeifer GP. Control of microtubule stability by the RASSF1A tumor suppressor. Oncogene 2003; 22: 8125-8136

74 Dreijerink K, Braga E, Kuzmin I, Geil L, Duh FM, Angeloni D, Zbar B, Lerman MI, Stanbridge EJ, Minna JD, Protopopov A, Li J, Kashuba V, Klein G, Zabarovsky ER. The candidate tumor suppressor gene, RASSF1A, from human chromosome 3 p21.3 is involved in kidney tumorigenesis. Proc Natl Acad Sci USA 2001; 98: 7504-7509

75 Schagdarsurengin U, Wilkens L, Steinemann D, Flemming P, Kreipe HH, Pfeifer GP, Schlegelberger B, Dammann R. Frequent epigenetic inactivation of the RASSF1A gene in hepatocellular carcinoma. Oncogene 2003; 22: 1866-1871

76 Zhong S, Yeo W, Tang MW, Wong N, Lai PB, Johnson PJ. Intensive hypermethylation of the $\mathrm{CpG}$ island of Ras association domain family $1 \mathrm{~A}$ in hepatitis $\mathrm{B}$ virus-associated hepatocellular carcinomas. Clin Cancer Res 2003; 9: 3376-3382

77 Qiu GH, Tan LK, Loh KS, Lim CY, Srivastava G, Tsai ST, Tsao $\mathrm{SW}$, Tao Q. The candidate tumor suppressor gene BLU, located at the commonly deleted region 3p21.3, is an E2F-regulated, stress-responsive gene and inactivated by both epigenetic and genetic mechanisms in nasopharyngeal carcinoma. Oncogene 2004; 23: 4793-4806

78 Agathanggelou A, Dallol A, Zochbauer-Muller S, Morrissey C, Honorio S, Hesson L, Martinsson T, Fong KM, Kuo MJ, Yuen PW, Maher ER, Minna JD, Latif F. Epigenetic inactivation of the candidate 3 p21.3 suppressor gene BLU in human cancers. Oncogene 2003; 22: 1580-1588

79 Tomizawa Y, Sekido Y, Kondo M, Gao B, Yokota J, Roche J, Drabkin H, Lerman MI, Gazdar AF, Minna JD. Inhibition of lung cancer cell growth and induction of apoptosis after reexpression of $3 \mathrm{p} 21.3$ candidate tumor suppressor gene SEMA3B. Proc Natl Acad Sci USA 2001; 98: 13954-13959

80 Castro-Rivera E, Ran S, Thorpe P, Minna JD. Semaphorin 3B (SEMA3B) induces apoptosis in lung and breast cancer, whereas VEGF165 antagonizes this effect. Proc Natl Acad Sci USA 2004; 101: 11432-11437

81 Kuroki T, Trapasso F, Yendamuri S, Matsuyama A, Alder H, Williams NN, Kaiser LR, Croce CM. Allelic loss on chromosome 3p21.3 and promoter hypermethylation of semaphorin 3B in non-small cell lung cancer. Cancer Res 2003; 63: 3352-3355

82 Hesson L, Bieche I, Krex D, Criniere E, Hoang-Xuan K, Maher ER, Latif F. Frequent epigenetic inactivation of RASSF1A and BLU genes located within the critical 3p21.3 region in gliomas. Oncogene 2004; 23: 2408-2419

83 Mitelman F, Mertens F, Johansson B. A breakpoint map of recurrent chromosomal rearrangements in human neoplasia. Nat Genet 1997; 15: 417-474

84 Smeets DF, Scheres JM, Hustinx TW. The most common fragile site in man is 3p14. Hum Genet 1986; 72: 215-220

85 Zochbauer-Muller S, Fong KM, Maitra A, Lam S, Geradts J, Ashfaq R, Virmani AK, Milchgrub S, Gazdar AF, Minna JD. 5' CpG island methylation of the FHIT gene is correlated with loss of gene expression in lung and breast cancer. Cancer Res 
2001; 61: 3581-3585

86 Sun Y, Geng XP, Zhu LX, Xiong QR, Qian YB, Dong GY, Li XM. Clinicopathological significance of aberrant methylation of the fragile histidine triad gene in patients with hepatocellular carcinoma. Zhonghua Waike Zazhi 2006; 44: 609-612

87 Toyota M, Ahuja N, Ohe-Toyota M, Herman JG, Baylin SB, Issa JP. CpG island methylator phenotype in colorectal cancer. Proc Natl Acad Sci USA 1999; 96: 8681-8686

88 Toyota M, Ahuja N, Suzuki H, Itoh F, Ohe-Toyota M, Imai $\mathrm{K}$, Baylin SB, Issa JP. Aberrant methylation in gastric cancer associated with the $\mathrm{CpG}$ island methylator phenotype. Cancer Res 1999; 59: 5438-5442

89 Shen L, Ahuja N, Shen Y, Habib NA, Toyota M, Rashid A, Issa JP. DNA methylation and environmental exposures in human hepatocellular carcinoma. J Natl Cancer Inst 2002; 94: 755-761

90 Liu WJ, Wang L, Wang JP, Li JQ, Zhang CQ, Zheng L, Yuan YF. Correlations of CpG island methylator phenotype and OPCML gene methylation to carcinogenesis of hepatocellular carcinoma. Ai Zheng 2006; 25: 696-700

91 Zhang C, Li Z, Cheng Y, Jia F, Li R, Wu M, Li K, Wei L. CpG island methylator phenotype association with elevated serum alpha-fetoprotein level in hepatocellular carcinoma. Clin Cancer Res 2007; 13: 944-952

92 Bestor TH. Activation of mammalian DNA methyltransferase by cleavage of a Zn binding regulatory domain. EMBO J 1992; 11: $2611-2617$

93 Saito Y, Kanai Y, Sakamoto M, Saito H, Ishii H, Hirohashi S. Expression of mRNA for DNA methyltransferases and methylCpG-binding proteins and DNA methylation status on CpG islands and pericentromeric satellite regions during human hepatocarcinogenesis. Hepatology 2001; 33: 561-568

94 Nagai M, Nakamura A, Makino R, Mitamura K. Expression of DNA (5-cytosin)-methyltransferases (DNMTs) in hepatocellular carcinomas. Hepatol Res 2003; 26: 186-191

95 Goll MG, Kirpekar F, Maggert KA, Yoder JA, Hsieh CL, Zhang X, Golic KG, Jacobsen SE, Bestor TH. Methylation of tRNAAsp by the DNA methyltransferase homolog Dnmt2. Science 2006; 311: 395-398

96 Park HJ, Yu E, Shim YH. DNA methyltransferase expression and DNA hypermethylation in human hepatocellular carcinoma. Cancer Lett 2006; 233: 271-278

97 Saito Y, Kanai Y, Nakagawa T, Sakamoto M, Saito H, Ishii $\mathrm{H}$, Hirohashi S. Increased protein expression of DNA methyltransferase (DNMT) 1 is significantly correlated with the malignant potential and poor prognosis of human hepatocellular carcinomas. Int J Cancer 2003; 105: 527-532

98 Choi MS, Shim YH, Hwa JY, Lee SK, Ro JY, Kim JS, Yu E. Expression of DNA methyltransferases in multistep hepatocarcinogenesis. Hum Pathol 2003; 34: 11-17

99 Eads CA, Danenberg KD, Kawakami K, Saltz LB, Danenberg PV, Laird PW. CpG island hypermethylation in human colorectal tumors is not associated with DNA methyltransferase overexpression. Cancer Res 1999; 59: 2302-2306
100 Feo F, Pascale RM, Simile MM, De Miglio MR, Muroni MR, Calvisi D. Genetic alterations in liver carcinogenesis: implications for new preventive and therapeutic strategies. Crit Rev Oncog 2000; 11: 19-62

101 Chuang LS, Ian HI, Koh TW, Ng HH, Xu G, Li BF. Human DNA-(cytosine-5) methyltransferase-PCNA complex as a target for p21WAF1. Science 1997; 277: 1996-2000

102 Saito Y, Kanai Y, Sakamoto M, Saito H, Ishii H, Hirohashi S. Overexpression of a splice variant of DNA methyltransferase 3b, DNMT3b4, associated with DNA hypomethylation on pericentromeric satellite regions during human hepatocarcinogenesis. Proc Natl Acad Sci USA 2002; 99: 10060-10065

103 Gama-Sosa MA, Slagel VA, Trewyn RW, Oxenhandler R, Kuo KC, Gehrke CW, Ehrlich M. The 5-methylcytosine content of DNA from human tumors. Nucleic Acids Res 1983; 11: 6883-6894

104 Kim YI, Giuliano A, Hatch KD, Schneider A, Nour MA, Dallal GE, Selhub J, Mason JB. Global DNA hypomethylation increases progressively in cervical dysplasia and carcinoma. Cancer 1994; 74: 893-899

105 Bedford MT, van Helden PD. Hypomethylation of DNA in pathological conditions of the human prostate. Cancer Res 1987; 47: 5274-5276

106 Feinberg AP, Gehrke CW, Kuo KC, Ehrlich M. Reduced genomic 5-methylcytosine content in human colonic neoplasia. Cancer Res 1988; 48: 1159-1161

107 Cravo M, Pinto R, Fidalgo P, Chaves P, Gloria L, Nobre-Leitao C, Costa Mira F. Global DNA hypomethylation occurs in the early stages of intestinal type gastric carcinoma. Gut 1996; 39: 434-438

108 Shen L, Fang J, Qiu D, Zhang T, Yang J, Chen S, Xiao S. Correlation between DNA methylation and pathological changes in human hepatocellular carcinoma. Hepatogastroenterology 1998; 45: $1753-1759$

109 Lin CH, Hsieh SY, Sheen IS, Lee WC, Chen TC, Shyu WC, Liaw YF. Genome-wide hypomethylation in hepatocellular carcinogenesis. Cancer Res 2001; 61: 4238-4243

110 Bratthauer GL, Fanning TG. Active LINE-1 retrotransposons in human testicular cancer. Oncogene 1992; 7: 507-510

111 Jurgens B, Schmitz-Drager BJ, Schulz WA. Hypomethylation of L1 LINE sequences prevailing in human urothelial carcinoma. Cancer Res 1996; 56: 5698-5703

112 Florl AR, Lower R, Schmitz-Drager BJ, Schulz WA. DNA methylation and expression of LINE-1 and HERV-K provirus sequences in urothelial and renal cell carcinomas. $\mathrm{Br} J$ Cancer 1999; 80: 1312-1321

113 Lee JS, Chu IS, Heo J, Calvisi DF, Sun Z, Roskams T, Durnez A, Demetris AJ, Thorgeirsson SS. Classification and prediction of survival in hepatocellular carcinoma by gene expression profiling. Hepatology 2004; 40: 667-676

114 Cui R, Nguyen TT, Taube JH, Stratton SA, Feuerman MH, Barton MC. Family members p53 and p73 act together in chromatin modification and direct repression of alphafetoprotein transcription. J Biol Chem 2005; 280: 39152-39160

S- Editor Liu JN E- Editor Yin DH 